\title{
Cholecystokinin receptors (version 2019.4) in the IUPHAR/BPS Guide to Pharmacology Database
}

\author{
Margery Beinfeld ${ }^{1}$, Quan Chen², Fan Gao², Roger A. Liddle ${ }^{3}$, Laurence J. Miller ${ }^{2}$ and Jens Rehfeld ${ }^{4}$ \\ 1. Tufts University, USA \\ 2. Mayo Clinic, USA \\ 3. Duke University, USA \\ 4. University of Copenhagen, Denmark
}

\begin{abstract}
Cholecystokinin receptors (nomenclature as agreed by the NC-IUPHAR Subcommittee on CCK receptors [89]) are activated by the endogenous peptides cholecystokinin-8 CCK-8), CCK-33, CCK-58 and gastrin (gastrin-17). There are only two distinct subtypes of CCK receptors, $\mathrm{CCK}_{4}$ and $\mathrm{CCK}_{2}$ receptors [63, 123], with some alternatively spliced forms most often identified in neoplastic cells. The CCK receptor subtypes are distinguished by their peptide selectivity, with the $\mathrm{CCK}_{1}$ receptor requiring the carboxyl-terminal heptapeptideamide that includes a sulfated tyrosine for high affinity and potency, while the $\mathrm{CCK}_{2}$ receptor requires only the carboxyl-terminal tetrapeptide shared by each CCK and gastrin peptides. These receptors have characteristic and distinct distributions, with both present in both the central nervous system and peripheral tissues.
\end{abstract}

\section{Contents}

This is a citation summary for Cholecystokinin receptors in the Guide to Pharmacology database (GtoPdb). It exists purely as an adjunct to the database to facilitate the recognition of citations to and from the database by citation analyzers. Readers will almost certainly want to visit the relevant sections of the database which are given here under database links.

GtoPdb is an expert-driven guide to pharmacological targets and the substances that act on them. GtoPdb is a reference work which is most usefully represented as an on-line database. As in any publication this work should be appropriately cited, and the papers it cites should also be recognized. This document provides a citation for the relevant parts of the database, and also provides a reference list for the research cited by those parts.

Please note that the database version for the citations given in GtoPdb are to the most recent preceding version in which the family or its subfamilies and targets were substantially changed. The links below are to the current version. If you need to consult the cited version, rather than the most recent version, please contact the GtoPdb curators.

\section{Database links}

Cholecystokinin receptors

http://www.guidetopharmacology.org/GRAC/FamilyDisplayForward?familyld=15 
Introduction to Cholecystokinin receptors

http://www.guidetopharmacology.org/GRAC/FamilyIntroductionForward?familyld=15

Receptors

$\mathrm{CCK}_{1}$ receptor

http://www.guidetopharmacology.org/GRAC/ObjectDisplayForward?objectld=76

$\mathrm{CCK}_{2}$ receptor

http://www.guidetopharmacology.org/GRAC/ObjectDisplayForward?objectld=77

\section{References}

1. Akgün E, Körner M, Gao F, Harikumar KG, Waser B, Reubi JC, Portoghese PS and Miller LJ. (2009) Synthesis and in vitro characterization of radioiodinatable benzodiazepines selective for type 1 and type 2 cholecystokinin receptors. J. Med. Chem. 52: 2138-47 [PMID:19271701]

2. Akiyama T, Tachibana I, Hirohata Y, Shirohara H, Yamamoto M and Otsuki M. (1996) Pharmacological profile of TP-680, a new cholecystokininA receptor antagonist. Br. J. Pharmacol. 117: 1558-64 [PMID:8730754]

3. Andersen BN. (1984) Measurement and occurrence of sulfated gastrins.Scand. J. Clin. Lab. Invest. Suppl. 168: 5-24 [PMID:6387882]

4. Aquino CJ, Armour DR, Berman JM, Birkemo LS, Carr RA, Croom DK, Dezube M, Dougherty RW, Ervin GN, Grizzle MK, Head JE, Hirst GC, James MK, Johnson MF, Miller LJ, Queen KL, Rimele TJ, Smith DN and Sugg EE. (1996) Discovery of 1,5-benzodiazepines with peripheral cholecystokinin (CCK-A) receptor agonist activity. 1. Optimization of the agonist "trigger". J Med Chem 39: 562-569 [PMID:8558528]

5. Asin KE, Bednarz L, Nikkel AL, Gore Jr PA, Montana WE, Cullen MJ, Shiosaki K, Craig R and Nadzan AM. (1992) Behavioral effects of A71623, a highly selective CCK-A agonist tetrapeptide. Am. J. Physiol. 263: R125-35 [PMID:1636779]

6. Attoub S, Levasseur S, Buyse M, Goïot H, Laigneau JP, Moizo L, Hervatin F, Le Marchand-Brustel Y, Lewin JM and Bado A. (1999) Physiological role of cholecystokinin B/gastrin receptor in leptin secretion. Endocrinology 140: 4406-10 [PMID:10499492]

7. Augelli-Szafran CE, Horwell DC, Kneen C, Ortwine DF, Pritchard MC, Purchase TS, Roth BD, Trivedi BK, Hill D and Suman-Chauhan N et al.. (1996) Cholecystokinin B antagonists. Synthesis and quantitative structure-activity relationships of a series of C-terminal analogues of Cl-988. Bioorg. Med. Chem. 4: 173345 [PMID:8931944]

8. Bellier B, Dugave C, Etivant F, Genet R, Gigoux V and Garbay C. (2004) Synthesis and biological characterisation of $[3 \mathrm{H}] \mathrm{BBL} 454$, a new CCK2 selective radiolabelled agonist displaying original pharmacological properties. Bioorg. Med. Chem. Lett. 14: 369-72 [PMID:14698161]

9. Berna MJ, Tapia JA, Sancho V and Jensen RT. (2007) Progress in developing cholecystokinin (CCK)/gastrin receptor ligands that have therapeutic potential. Curr Opin Pharmacol 7: 583-92 [PMID:17997137]

10. Bertrand P, Böhme GA, Durieux C, Guyon C, Capet M, Jeantaud B, Boudeau P, Ducos B, Pendley CE and Martin GE et al.. (1994) Pharmacological properties of ureido-acetamides, new potent and selective non-peptide CCKB/gastrin receptor antagonists. Eur. J. Pharmacol. 262: 233-45 [PMID:7813588]

11. Bignon E, Bachy A, Boigegrain R, Brodin R, Cottineau M, Gully D, Herbert JM, Keane P, Labie C and Molimard JC et al.. (1999) SR146131: a new potent, orally active, and selective nonpeptide cholecystokinin subtype 1 receptor agonist. I. In vitro studies. J. Pharmacol. Exp. Ther. 289: 742-51 [PMID:10215648]

12. Blevins Jr GT, van de Westerlo EM, Yule DI and Williams JA. (1994) Characterization of cholecystokininA receptor agonist activity by a family of cholecystokininB receptor antagonists. J. Pharmacol. Exp. Ther. 269: 911-6 [PMID:7516969]

13. Boden P and Hill RG. (1988) Effects of cholecystokinin and related peptides on neuronal activity in the ventromedial nucleus of the rat hypothalamus. Br. J. Pharmacol. 94: 246-52 [PMID:3401640]

14. Boden PR, Higginbottom M, Hill DR, Horwell DC, Hughes J, Rees DC, Roberts E, Singh L, Suman- 
Chauhan N and Woodruff GN. (1993) Cholecystokinin dipeptoid antagonists: design, synthesis, and anxiolytic profile of some novel CCK-A and CCK-B selective and "mixed" CCK-A/CCK-B antagonists. $J$ Med Chem 36: 552-565 [PMID:7684452]

15. Boyce M, David O, Darwin K, Mitchell T, Johnston A and Warrington S. (2012) Single oral doses of netazepide (YF476), a gastrin receptor antagonist, cause dose-dependent, sustained increases in gastric pH compared with placebo and ranitidine in healthy subjects. Aliment. Pharmacol. Ther. 36: 181-9 [PMID:22607579]

16. Broberger C, Holmberg K, Shi TJ, Dockray G and Hökfelt T. (2001) Expression and regulation of cholecystokinin and cholecystokinin receptors in rat nodose and dorsal root ganglia. Brain Res. 903: 12840 [PMID:11382396]

17. Castro JL, Ball RG, Broughton HB, Russell MG, Rathbone D, Watt AP, Baker R, Chapman KL, Fletcher AE and Patel S et al.. (1996) Controlled modification of acidity in cholecystokinin B receptor antagonists: N(1,4-benzodiazepin-3-yl)-N'-[3-(tetrazol-5-ylamino) phenyl]ureas. J. Med. Chem. 39: 842-9 [PMID:8632408]

18. Chandra R and Liddle RA. (2007) Cholecystokinin. Curr Opin Endocrinol Diabetes Obes 14: 63-7 [PMID:17940422]

19. Chang RS, Lotti VJ, Chen TB and Kunkel KA. (1986) Characterization of the binding of [3H]-(+/-)-L364,718: a new potent, nonpeptide cholecystokinin antagonist radioligand selective for peripheral receptors. Mol. Pharmacol. 30: 212-7 [PMID:3018478]

20. Chao C, Goluszko E, Lee YT, Kolokoltsov AA, Davey RA, Uchida T, Townsend Jr CM and Hellmich MR. (2007) Constitutively active CCK2 receptor splice variant increases Src-dependent HIF-1 alpha expression and tumor growth. Oncogene 26: 1013-9 [PMID:16909104]

21. Chen D, Zhao CM, Al-Haider W, Håkanson R, Rehfeld JF and Kopin AS. (2002) Differentiation of gastric ECL cells is altered in CCK(2) receptor-deficient mice. Gastroenterology 123: 577-85 [PMID:12145810]

22. Clerc $P$, Coll Constans MG, Lulka H, Broussaud S, Guigné $C$, Leung-Theung-Long S, Perrin C, Knauf $C$, Carpéné $C$ and Pénicaud $L$ et al.. (2007) Involvement of cholecystokinin 2 receptor in food intake regulation: hyperphagia and increased fat deposition in cholecystokinin 2 receptor-deficient mice. Endocrinology 148: 1039-49 [PMID:17122076]

23. Clerc P, Dufresne M, Saillan C, Chastre E, André T, Escrieut C, Kennedy K, Vaysse N, Gespach C and Fourmy D. (1997) Differential expression of the CCK-A and CCK-B/gastrin receptor genes in human cancers of the esophagus, stomach and colon. Int J Cancer 72: 931-936 [PMID:9378553]

24. Covasa M and Ritter RC. (2005) Reduced CCK-induced Fos expression in the hindbrain, nodose ganglia, and enteric neurons of rats lacking CCK-1 receptors. Brain Res. 1051: 155-63 [PMID:16005445]

25. Cuq P, Gross A, Terraza A, Fourmy D, Clerc P, Dornand J and Magous R. (1997) mRNAs encoding CCKB but not CCKA receptors are expressed in human T lymphocytes and Jurkat lymphoblastoid cells. Life Sci. 61: 543-55 [PMID:9247324]

26. Dauge V, Derrien M, Durieux C, Noble F, Corringer PJ and Roques BP. (1992) [Study of induced effects by selective CCKB agonists cholecystokinin in the nociception and behavior in rodents]. Therapie 47: 5319 [PMID:1301645]

27. Daugherty D and Yamada T. (1989) Posttranslational processing of gastrin.Physiol. Rev. 69: 482-502 [PMID:2648420]

28. Daugé V, Sebret A, Beslot F, Matsui T and Roques BP. (2001) Behavioral profile of CCK2 receptordeficient mice. Neuropsychopharmacology 25: 690-8 [PMID:11682252]

29. de Weerth A, Pisegna JR, Huppi K and Wank SA. (1993) Molecular cloning, functional expression and chromosomal localization of the human cholecystokinin type A receptor. Biochem. Biophys. Res. Commun. 194: 811-8 [PMID:8343165]

30. Deschenes RJ, Lorenz LJ, Haun RS, Roos BA, Collier KJ and Dixon JE. (1984) Cloning and sequence analysis of a cDNA encoding rat preprocholecystokinin. Proc. Natl. Acad. Sci. U.S.A. 81: 726-30 [PMID:6199787]

31. Ding WQ, Kuntz SM and Miller LJ. (2002) A misspliced form of the cholecystokinin-B/gastrin receptor in pancreatic carcinoma: role of reduced sellular U2AF35 and a suboptimal 3 '-splicing site leading to 
retention of the fourth intron. Cancer Res. 62: 947-52 [PMID:11830556]

32. Dockray G, Dimaline R and Varro A. (2005) Gastrin: old hormone, new functions.Pflugers Arch. 449: 34455 [PMID:15480747]

33. Dong M, Liu G, Pinon DI and Miller LJ. (2005) Differential docking of high-affinity peptide ligands to type A and $B$ cholecystokinin receptors demonstrated by photoaffinity labeling. Biochemistry 44: 6693-700 [PMID:15850403]

34. Dourish CT, Ruckert AC, Tattersall FD and Iversen SD. (1989) Evidence that decreased feeding induced by systemic injection of cholecystokinin is mediated by CCK-A receptors. Eur. J. Pharmacol. 173: 233-4 [PMID:2625140]

35. Dunlop J, Brammer N and Ennis C. (1996) Pharmacological characterization of a Chinese hamster ovary cell line transfected with the human CCK-B receptor gene. Neuropeptides 30: 359-63 [PMID:8914862]

36. Durieux C, Ruiz-Gayo M, Corringer PJ, Bergeron F, Ducos B and Roques BP. (1992) [3H]pBC 264, a suitable probe for studying cholecystokinin-B receptors: binding characteristics in rodent brains and comparison with [3H]SNF 8702. Mol Pharmacol 41: 1089-1095 [PMID:1614411]

37. Edkins JS. (1905) On the chemical mechanism of gastric secretion.Proc Roy Soc B 76: 376-

38. Ellenberger HH and Smith FM. (1999) Sulfated cholecystokinin octapeptide in the rat: pontomedullary distribution and modulation of the respiratory pattern. Can. J. Physiol. Pharmacol. 77: 490-504 [PMID:10535709]

39. Elliott RL, Cameron KO, Chin JE, Bartlett JA, Beretta EE, Chen Y, Jardine Pda S, Dubins JS, Gillaspy ML and Hargrove DM et al.. (2010) Discovery of N-benzyl-2-[(4S)-4-(1H-indol-3-ylmethyl)-5-oxo-1-phenyl-4,5dihydro-6H-[1,2,4]triazolo[4,3-a][1,5]benzodiazepin-6-yl]-N-isopropylacetamide, an orally active, gutselective CCK1 receptor agonist for the potential treatment of obesity. Bioorg. Med. Chem. Lett. 20: 6797801 [PMID:20851601]

40. Feifel D, Shilling PD, Kuczenski R and Segal DS. (2003) Altered extracellular dopamine concentration in the brains of cholecystokinin-A receptor deficient rats. Neurosci. Lett. 348: 147-50 [PMID:12932815]

41. Flynn DL, Villamil CI, Becker DP, Gullikson GW, Moummi C and Yang D. (1992) 1,3,4-trisubstituted pyrrolidinones as scaffolds for construction of peptidomimetic cholecystokinin antagonists. Bioorg Med Chem Lett 2(10): 1251-1256

42. Gouldson P, Legoux P, Carillon C, Delpech B, Le Fur G, Ferrara P and Shire D. (2000) The agonist SR 146131 and the antagonist SR 27897 occupy different sites on the human CCK(1) receptor. Eur. J. Pharmacol. 400: 185-94 [PMID:10988332]

43. GREGORY RA and TRACY HJ. (1964) THE CONSTITUTION AND PROPERTIES OF TWO GASTRINS EXTRACTED FROM HOG ANTRAL MUCOSA. Gut 5: 103-14 [PMID:14159395]

44. Gully D, Fréhel D, Marcy C, Spinazzé A, Lespy L, Neliat G, Maffrand JP and Le Fur G. (1993) Peripheral biological activity of SR 27897: a new potent non-peptide antagonist of CCKA receptors. Eur. J. Pharmacol. 232: 13-9 [PMID:7681406]

45. Harper AA and Raper HS. (1943) Pancreozymin, a stimulant of the secretion of pancreatic enzymes in extracts of the small intestine. J. Physiol. (Lond.) 102: 115-25 [PMID:16991584]

46. Harper EA, Shankley NP and Black JW. (1999) Characterization of the binding of a novel radioligand to CCKB/gastrin receptors in membranes from rat cerebral cortex. Br. J. Pharmacol. 126: 1504-12 [PMID:10217546]

47. Hellmich MR, Rui XL, Hellmich HL, Fleming RY, Evers BM and Townsend Jr CM. (2000) Human colorectal cancers express a constitutively active cholecystokinin-B/gastrin receptor that stimulates cell growth. $J$. Biol. Chem. 275: 32122-8 [PMID:10913157]

48. Henke BR, Aquino CJ, Birkemo LS, Croom DK, Dougherty Jr RW, Ervin GN, Grizzle MK, Hirst GC, James MK and Johnson MF et al.. (1997) Optimization of 3-(1H-indazol-3-ylmethyl)-1,5-benzodiazepines as potent, orally active CCK-A agonists. J. Med. Chem. 40: 2706-25 [PMID:9276016]

49. Horwell DC, Hunter JC, Kneen CO and Pritchard MC. (1995) Synthesis of novel iodinated radioligands with high affinity and selectivity for CCK-B/gastrin receptors. Bioorganic and Medicinal Chemistry Letters 5: 2501-2506 
50. Hoshi H and Logsdon CD. (1993) Both low- and high-affinity CCK receptor states mediate trophic effects on rat pancreatic acinar cells. Am. J. Physiol. 265: G1177-81 [PMID:8279569]

51. Hughes J, Boden P, Costall B, Domeney A, Kelly E, Horwell DC, Hunter JC, Pinnock RD and Woodruff GN. (1990) Development of a class of selective cholecystokinin type B receptor antagonists having potent anxiolytic activity. Proc. Natl. Acad. Sci. U.S.A. 87: 6728-32 [PMID:1975695]

52. Hunter JC, Suman-Chauhan N, Meecham KG, Dissanayake VU, Hill DR, Pritchard MC, Kneen CO, Horwell DC, Hughes J and Woodruff GN. (1993) [3H]PD 140376: a novel and highly selective antagonist radioligand for the cholecystokininB/gastrin receptor in guinea pig cerebral cortex and gastric mucosa. Mol. Pharmacol. 43: 595-602 [PMID:8474432]

53. Innis RB and Snyder SH. (1980) Distinct cholecystokinin receptors in brain and pancreas.Proc. Natl. Acad. Sci. U.S.A. 77: 6917-21 [PMID:6256771]

54. Ito H, Sogabe H, Nakarai T, Sato Y, Tomoi M, Kadowaki M, Matsuo M, Tokoro K and Yoshida K. (1994) Pharmacological profile of FK480, a novel cholecystokinin type-A receptor antagonist: comparison to loxiglumide. J. Pharmacol. Exp. Ther. 268: 571-5 [PMID:7509389]

55. Ito M, Matsui T, Taniguchi T, Tsukamoto T, Murayama T, Arima N, Nakata H, Chiba T and Chihara K. (1993) Functional characterization of a human brain cholecystokinin-B receptor. A trophic effect of cholecystokinin and gastrin. J. Biol. Chem. 268: 18300-5 [PMID:8349705]

56. Ivy AC and Oldberg E. (1928) A hormone mechanism for gallbladder contraction and evacuation $A m ~ J$ Physiol 86: 599-613

57. Iwamoto Y, Yamamoto R and Kuzuya T. (1987) CR-1409: a potent inhibitor of cholecystokinin-stimulated amylase release and cholecystokinin binding in rat pancreatic acini. Pancreas 2: 85-90 [PMID:2437574]

58. Jagerschmidt A, Guillaume-Rousselet N, Vikland ML, Goudreau N, Maigret B and Roques BP. (1996) His381 of the rat CCKB receptor is essential for CCKB versus CCKA receptor antagonist selectivity. Eur. J. Pharmacol. 296: 97-106 [PMID:8720482]

59. Ji B, Bi Y, Simeone D, Mortensen RM and Logsdon CD. (2001) Human pancreatic acinar cells lack functional responses to cholecystokinin and gastrin. Gastroenterology 121: 1380-90 [PMID:11729117]

60. Kanagawa K, Nakamura H, Murata I, Yosikawa I and Otsuki M. (2002) Increased gastric acid secretion in cholecystokinin-1 receptor-deficient Otsuka Long-Evans Tokushima fatty rats. Scand. J. Gastroenterol. 37: 9-16 [PMID:11843043]

61. Kawasaki D, Emori Y, Eta R, lino Y, Hamano H, Yoshinaga K, Tanaka T, Takei M and Watson SA. (2008) Effect of Z-360, a novel orally active CCK-2/gastrin receptor antagonist on tumor growth in human pancreatic adenocarcinoma cell lines in vivo and mode of action determinations in vitro. Cancer Chemother. Pharmacol. 61: 883-92 [PMID:17901954]

62. Kennedy K, Escrieut C, Dufresne M, Clerc P, Vaysse N and Fourmy D. (1995) Identification of a region of the $\mathrm{N}$-terminal of the human CCKA receptor essential for the high affinity interaction with agonist CCK. Biochem. Biophys. Res. Commun. 213: 845-52 [PMID:7654246]

63. Kopin AS, Lee YM, McBride EW, Miller LJ, Lu M, Lin HY, Kolakowski Jr LF and Beinborn M. (1992) Expression cloning and characterization of the canine parietal cell gastrin receptor. Proc. Natl. Acad. Sci. U.S.A. 89: 3605-9 [PMID:1373504]

64. Kulaksiz H, Arnold R, Göke B, Maronde E, Meyer M, Fahrenholz F, Forssmann WG and Eissele R. (2000) Expression and cell-specific localization of the cholecystokinin B/gastrin receptor in the human stomach. Cell Tissue Res. 299: 289-98 [PMID:10741470]

65. Kuwahara T, Kudoh T, Nakano A, Yoshizaki H, Takamiya M, Nagase H and Arisawa M. (1993) Species specificity of pharmacological characteristics of CCK-B receptors. Neurosci. Lett. 158: 1-4 [PMID:8233061]

66. Lacourse KA, Lay JM, Swanberg LJ, Jenkins C and Samuelson LC. (1997) Molecular structure of the mouse CCK-A receptor gene. Biochem. Biophys. Res. Commun. 236: 630-5 [PMID:9245702]

67. Ladurelle N, Roques BP and Daugé V. (1995) The transfer of rats from a familiar to a novel environment prolongs the increase of extracellular dopamine efflux induced by CCK8 in the posterior nucleus accumbens. J. Neurosci. 15: 3118-27 [PMID:7722650]

68. Langhans N, Rindi G, Chiu M, Rehfeld JF, Ardman B, Beinborn M and Kopin AS. (1997) Abnormal gastric 
histology and decreased acid production in cholecystokinin-B/gastrin receptor-deficient mice. Gastroenterology 112: 280-6 [PMID:8978369]

69. Latorre M, Bartolomé-Nebreda JM, García-López MT, González-Muñiz R, Herranz R, Del Río J and Cenarruzabeitia E. (2004) Pharmacological study of IQM-97,423, a potent and selective CCK1 receptor antagonist with protective effect in experimental acute pancreatitis. Pharmacology 72: 68-76 [PMID:15331911]

70. Lee YM, Beinborn M, McBride EW, Lu M, Kolakowski Jr LF and Kopin AS. (1993) The human brain cholecystokinin-B/gastrin receptor. Cloning and characterization. J. Biol. Chem. 268: 8164-9 [PMID:7681836]

71. Liddle RA, Goldfine ID and Williams JA. (1984) Bioassay of plasma cholecystokinin in rats: effects of food, trypsin inhibitor, and alcohol. Gastroenterology 87: 542-9 [PMID:6204904]

72. Lindström E, Björkqvist M and Håkanson R. (1999) Pharmacological analysis of CCK2 receptor antagonists using isolated rat stomach ECL cells. Br. J. Pharmacol. 127: 530-6 [PMID:10385255]

73. Makovec F, Bani M, Cereda R, Chisté R, Pacini MA, Revel L, Rovati LA, Rovati LC and Setnikar I. (1987) Pharmacological properties of lorglumide as a member of a new class of cholecystokinin antagonists. Arzneimittelforschung 37: 1265-8 [PMID:3440035]

74. Makovec F, Revel L, Letari O, Mennuni L and Impicciatore M. (1999) Characterization of antisecretory and antiulcer activity of CR 2945, a new potent and selective gastrin/CCK(B) receptor antagonist. Eur. J. Pharmacol. 369: 81-90 [PMID:10204685]

75. Marino CR, Leach SD, Schaefer JF, Miller LJ and Gorelick FS. (1993) Characterization of CAMPdependent protein kinase activation by CCK in rat pancreas. FEBS Lett. 316: 48-52 [PMID:7678554]

76. Mazzocchi G, Malendowicz LK, Aragona F, Spinazzi R and Nussdorfer GG. (2004) Cholecystokinin (CCK) stimulates aldosterone secretion from human adrenocortical cells via CCK2 receptors coupled to the adenylate cyclase/protein kinase A signaling cascade. J. Clin. Endocrinol. Metab. 89: 1277-84 [PMID:15001623]

77. Miller LJ, Holicky EL, Ulrich CD and Wieben ED. (1995) Abnormal processing of the human cholecystokinin receptor gene in association with gallstones and obesity. Gastroenterology 109: 1375-80 [PMID:7557108]

78. Monstein HJ, Nylander AG, Salehi A, Chen D, Lundquist I and Håkanson R. (1996) Cholecystokinin-A and cholecystokinin-B/gastrin receptor mRNA expression in the gastrointestinal tract and pancreas of the rat and man. A polymerase chain reaction study. Scand. J. Gastroenterol. 31: 383-90 [PMID:8726308]

79. Moon SJ, An JM, Kim J, Lee SI, Ahn W, Kim KH and Seo JT. (2004) Pharmacological characterization of rebamipide: its cholecystokinin CCK1 receptor binding profile and effects on $\mathrm{Ca} 2+$ mobilization and amylase release in rat pancreatic acinar cells. Eur. J. Pharmacol. 505: 61-6 [PMID:15556137]

80. Moriarty P, Dimaline R, Thompson DG and Dockray GJ. (1997) Characterization of cholecystokininA and cholecystokininB receptors expressed by vagal afferent neurons. Neuroscience 79: 905-13 [PMID:9219953]

81. Morisset J, Julien S and Lainé J. (2003) Localization of cholecystokinin receptor subtypes in the endocine pancreas. J. Histochem. Cytochem. 51: 1501-13 [PMID:14566022]

82. Morley JS. (1968) Structure--function relationships in gastrin-like peptides.Proc. R. Soc. Lond., B, Biol. Sci. 170: 97-111 [PMID:4385256]

83. Morton MF, Barrett TD, Freedman J, Li L, Rizzolio MC, Prendergast CE, Wu X, Moreno V, Pyati J and Figueroa $\mathrm{K}$ et al.. (2011) JNJ-26070109 [(R)4-bromo-N-[1-(2,4-difluoro-phenyl)-ethyl]-2-(quinoxaline-5sulfonylamino)-benzamide]: a novel, potent, and selective cholecystokinin 2 receptor antagonist with good oral bioavailability. J. Pharmacol. Exp. Ther. 338: 328-36 [PMID:21493750]

84. Morton MF, Barrett TD, Yan W, Freedman JM, Lagaud G, Prendergast CE, Moreno V, Pyati J, Figueroa K and Li L et al.. (2007) 3-[5-(3,4-Dichloro-phenyl)-1-(4-methoxy-phenyl)-1H-pyrazol-3-yl]-2-m-tolylpropionate (JNJ-17156516), a novel, potent, and selective cholecystokinin 1 receptor antagonist: in vitro and in vivo pharmacological comparison with dexloxiglumide. J. Pharmacol. Exp. Ther. 323: 562-9 [PMID:17684117] 
85. Mutt V and Jorpes JE. (1968) Structure of porcine cholecystokinin-pancreozymin. 1. Cleavage with thrombin and with trypsin. Eur. J. Biochem. 6: 156-62 [PMID:5725809]

86. Nagata A, Ito M, Iwata N, Kuno J, Takano H, Minowa O, Chihara K, Matsui T and Noda T. (1996) G protein-coupled cholecystokinin-B/gastrin receptors are responsible for physiological cell growth of the stomach mucosa in vivo. Proc. Natl. Acad. Sci. U.S.A. 93: 11825-30 [PMID:8876222]

87. Nilsson I, Monstein HJ, Lindström E, Håkanson R and Svensson S. (2002) Pharmacological analysis of CCK(2) receptor ligands using COS-7 and SK-N-MC cells, expressing the human CCK(2) receptor. Regul. Pept. 103: 29-37 [PMID:11738246]

88. Nishida A, Miyata K, Tsutsumi R, Yuki H, Akuzawa S, Kobayashi A, Kamato T, Ito H, Yamano M and Katuyama $Y$ et al.. (1994) Pharmacological profile of (R)-1-[2,3-dihydro-1-(2'-methylphenacyl)-2-oxo- 5phenyl-1H-1,4-benzodiazepin-3-yl]-3-(3-methylphenyl)urea (YM022), a new potent and selective gastrin/cholecystokinin-B receptor antagonist, in vitro and in vivo. J. Pharmacol. Exp. Ther. 269: 725-31 [PMID:7910212]

89. Noble F, Wank SA, Crawley JN, Bradwejn J, Seroogy KB, Hamon M and Roques BP. (1999) International Union of Pharmacology. XXI. Structure, distribution, and functions of cholecystokinin receptors. Pharmacol Rev 51: 745-781 [PMID:10581329]

90. Nomoto S, Miyake M, Ohta M, Funakoshi A and Miyasaka K. (1999) Impaired learning and memory in OLETF rats without cholecystokinin (CCK)-A receptor. Physiol Behav 66: 869-872 [PMID:10405116]

91. Patel S, Smith AJ, Chapman KL, Fletcher AE, Kemp JA, Marshall GR, Hargreaves RJ, Ryecroft W, Iversen LL and Iversen SD et al.. (1994) Biological properties of the benzodiazepine amidine derivative L-740,093, a cholecystokinin-B/gastrin receptor antagonist with high affinity in vitro and high potency in vivo. Mol. Pharmacol. 46: 943-8 [PMID:7969084]

92. Pisegna JR, de Weerth A, Huppi K and Wank SA. (1992) Molecular cloning of the human brain and gastric cholecystokinin receptor: structure, functional expression and chromosomal localization. Biochem.

Biophys. Res. Commun. 189: 296-303 [PMID:1280419]

93. Powers SP, Pinon DI and Miller LJ. (1988) Use of N,O-bis-Fmoc-D-Tyr-ONSu for introduction of an oxidative iodination site into cholecystokinin family peptides. Int. J. Pept. Protein Res. 31: 429-34 [PMID:3410633]

94. Rasmussen SG, Choi HJ, Fung JJ, Pardon E, Casarosa P, Chae PS, Devree BT, Rosenbaum DM, Thian FS and Kobilka TS et al.. (2011) Structure of a nanobody-stabilized active state of the $\beta(2)$ adrenoceptor. Nature 469: 175-80 [PMID:21228869]

95. Reeve Jr JR, McVey DC, Bunnett NW, Solomon TE, Keire DA, Ho FJ, Davis MT, Lee TD, Shively JE and Vigna SR. (2002) Differences in receptor binding and stability to enzymatic digestion between CCK-8 and CCK-58. Pancreas 25: e50-5 [PMID:12370550]

96. Rettenbacher M and Reubi JC. (2001) Localization and characterization of neuropeptide receptors in human colon. Naunyn Schmiedebergs Arch. Pharmacol. 364: 291-304 [PMID:11683516]

97. Reubi JC, Waser B, Gugger M, Friess H, Kleeff J, Kayed H, Büchler MW and Laissue JA. (2003) Distribution of CCK1 and CCK2 receptors in normal and diseased human pancreatic tissue. Gastroenterology 125: 98-106 [PMID:12851875]

98. Reubi JC, Waser B, Läderach U, Stettler C, Friess H, Halter F and Schmassmann A. (1997) Localization of cholecystokinin A and cholecystokinin B-gastrin receptors in the human stomach. Gastroenterology 112: 1197-205 [PMID:9098003]

99. Reubi JC, Waser B, Schmassmann A and Laissue JA. (1999) Receptor autoradiographic evaluation of cholecystokinin, neurotensin, somatostatin and vasoactive intestinal peptide receptors in gastro-intestinal adenocarcinoma samples: where are they really located? Int. J. Cancer 81: 376-86 [PMID:10209952]

100. Rodriguez M, Lignon MF, Galas MC, Amblard M and Martinez J. (1990) Cyclic cholecystokinin analogues that are highly selective for rat and guinea pig central cholecystokinin receptors. Mol Pharmacol 38: 333341 [PMID:1698251]

101. Saillan-Barreau C, Dufresne M, Clerc P, Sanchez D, Corominola H, Moriscot C, Guy-Crotte O, Escrieut C, Vaysse $\mathrm{N}$ and Gomis $\mathrm{R}$ et al.. (1999) Evidence for a functional role of the cholecystokinin-B/gastrin 
receptor in the human fetal and adult pancreas. Diabetes 48: 2015-21 [PMID:10512367]

102. Schmitz F, Göke MN, Otte JM, Schrader H, Reimann B, Kruse ML, Siegel EG, Peters J, Herzig KH, Fölsch UR and Schmidt WE. (2001) Cellular expression of CCK-A and CCK-B/gastrin receptors in human gastric mucosa. Regulatory Peptides 102: 101-110 [PMID:11730982]

103. Schmitz F, Schrader H, Otte J, Schmitz H, Stüber E, Herzig K and Schmidt WE. (2001) Identification of CCK-B/gastrin receptor splice variants in human peripheral blood mononuclear cells. Regul. Pept. 101: 2533 [PMID:11495676]

104. Sebret A, Léna I, Crété D, Matsui T, Roques BP and Daugé V. (1999) Rat hippocampal neurons are critically involved in physiological improvement of memory processes induced by cholecystokinin-B receptor stimulation. J. Neurosci. 19: 7230-7 [PMID:10436075]

105. Semple G, Ryder H, Rooker DP, Batt AR, Kendrick DA, Szelke M, Ohta M, Satoh M, Nishida A and Akuzawa S et al.. (1997) (3R)-N-(1-(tert-butylcarbonylmethyl)-2,3-dihydro-2-oxo-5-(2-pyridyl)-1H-1,4benzodiazepin-3-yl)-N'-(3-(methylamino)phenyl)urea (YF476): a potent and orally active gastrin/CCK-B antagonist. J. Med. Chem. 40: 331-41 [PMID:9022799]

106. Setnikar I, Bani M, Cereda R, Chisté R, Makovec F, Pacini MA, Revel L, Rovati LC and Rovati LA. (1987) Pharmacological characterisation of a new potent and specific nonpolypeptidic cholecystokinin antagonist. Arzneimittelforschung 37: 703-7 [PMID:3663268]

107. Simmons RD, Kaiser FC, Pierson ME and Rosamond JR. (1998) ARL 15849: a selective CCK-A agonist with anorectic activity in the rat and dog. Pharmacol. Biochem. Behav. 59: 439-44 [PMID:9476993]

108. Singh L, Field MJ, Hill DR, Horwell DC, McKnight AT, Roberts E, Tang KW and Woodruff GN. (1995) Peptoid CCK receptor antagonists: pharmacological evaluation of CCKA, CCKB and mixed CCKA/B receptor antagonists. Eur. J. Pharmacol. 286: 185-91 [PMID:8605955]

109. Smith JP, Verderame MF, McLaughlin P, Martenis M, Ballard E and Zagon IS. (2002) Characterization of the CCK-C (cancer) receptor in human pancreatic cancer. Int. J. Mol. Med. 10: 689-94 [PMID:12429993]

110. Song I, Brown DR, Wiltshire RN, Gantz I, Trent JM and Yamada T. (1993) The human gastrin/cholecystokinin type $B$ receptor gene: alternative splice donor site in exon 4 generates two variant mRNAs. Proc. Natl. Acad. Sci. U.S.A. 90: 9085-9 [PMID:8415658]

111. Takata $Y$, Takiguchi S, Funakoshi A and Kono A. (1995) Gene structure of rat cholecystokinin type-A receptor. Biochem. Biophys. Res. Commun. 213: 958-66 [PMID:7654260]

112. Takata Y, Takiguchi S, Kataoka K, Funakoshi A, Miyasaka K and Kono A. (1997) Mouse cholecystokinin type-A receptor gene and its structural analysis. Gene 187: 267-71 [PMID:9099891]

113. Takinami Y, Yuki H, Nishida A, Akuzawa S, Uchida A, Takemoto Y, Ohta M, Satoh M, Semple G and Miyata K. (1997) YF476 is a new potent and selective gastrin/cholecystokinin-B receptor antagonist in vitro and in vivo. Aliment. Pharmacol. Ther. 11: 113-20 [PMID:9042983]

114. Tang C, Biemond I and Lamers CB. (1996) Cholecystokinin receptors in human pancreas and gallbladder muscle: a comparative study. Gastroenterology 111: 1621-6 [PMID:8942742]

115. Taniguchi H, Yazaki N, Endo T and Nagasaki M. (1996) Pharmacological profile of T-0632, a novel potent and selective CCKA receptor antagonist, in vitro. Eur. J. Pharmacol. 304: 147-54 [PMID:8813597]

116. Tokunaga Y, Cox KL, Coleman R, Concepcion W, Nakazato P and Esquivel CO. (1993) Characterization of cholecystokinin receptors on the human gallbladder. Surgery 113: 155-62 [PMID:7679224]

117. Trivedi BK, Padia JK, Holmes A, Rose S, Wright DS, Hinton JP, Pritchard MC, Eden JM, Kneen C and Webdale L et al.. (1998) Second generation "peptoid" CCK-B receptor antagonists: identification and development of $\mathrm{N}$-(adamantyloxycarbonyl)-alpha-methyl-(R)-tryptophan derivative $(\mathrm{Cl}-1015)$ with an improved pharmacokinetic profile. J. Med. Chem. 41: 38-45 [PMID:9438020]

118. Ulrich CD, Ferber I, Holicky E, Hadac E, Buell G and Miller LJ. (1993) Molecular cloning and functional expression of the human gallbladder cholecystokinin A receptor. Biochem. Biophys. Res. Commun. 193: 204-11 [PMID:8503909]

119. Ursini A, Capelli AM, Carr RA, Cassarà P, Corsi M, Curcuruto O, Curotto G, Dal Cin M, Davalli S and Donati D et al.. (2000) Synthesis and SAR of new 5-phenyl-3-ureido-1,5-benzodiazepines as cholecystokinin-B receptor antagonists. J. Med. Chem. 43: 3596-613 [PMID:11020274] 
120. Vanderhaeghen JJ, Signeau JC and Gepts W. (1975) New peptide in the vertebrate CNS reacting with antigastrin antibodies. Nature 257: 604-5 [PMID:1165787]

121. Varnavas A, Lassiani L, Valenta V, Berti F, Mennuni L and Makovec F. (2003) Anthranilic acid derivatives: a new class of non-peptide CCK1 receptor antagonists. Bioorg. Med. Chem. 11: 741-51 [PMID:12538004]

122. Wang DQ, Schmitz F, Kopin AS and Carey MC. (2004) Targeted disruption of the murine cholecystokinin1 receptor promotes intestinal cholesterol absorption and susceptibility to cholesterol cholelithiasis. J. Clin. Invest. 114: 521-8 [PMID:15314689]

123. Wank SA, Harkins R, Jensen RT, Shapira H, de Weerth A and Slattery T. (1992) Purification, molecular cloning, and functional expression of the cholecystokinin receptor from rat pancreas. Proc. Natl. Acad. Sci. U.S.A. 89: 3125-9 [PMID:1313582]

124. Wank SA, Pisegna JR and de Weerth A. (1992) Brain and gastrointestinal cholecystokinin receptor family: structure and functional expression. Proc. Natl. Acad. Sci. U.S.A. 89: 8691-5 [PMID:1528881]

125. Whited KL, Thao D, Lloyd KC, Kopin AS and Raybould HE. (2006) Targeted disruption of the murine CCK1 receptor gene reduces intestinal lipid-induced feedback inhibition of gastric function. Am. J. Physiol. Gastrointest. Liver Physiol. 291: G156-62 [PMID:16574983]

126. Williams JA. (2001) Intracellular signaling mechanisms activated by cholecystokinin-regulating synthesis and secretion of digestive enzymes in pancreatic acinar cells. Annu. Rev. Physiol. 63: 77-97 [PMID:11181949] 